\title{
VÉGZETT HALLGATÓK ELVÁRT MUNKAERŐPIACI KOMPETENCIÁINAK VIZSGÁLATA
}

\author{
Kis Krisztián - Hampel György - Benkő-Kiss Árpád
}

\begin{abstract}
Absztrakt: Az egyetemi (kari) képzési kínálat és a végzett hallgatókkal kapcsolatos vállalati elvárások közötti kapcsolatokat, az igényelt kompetenciákat vizsgáltuk a tanulmányban. A vizsgálat primer adatfelvételeken (kérdőívek, interjúk) alapult.

Az eredmények azt mutatják, hogy a szakmai kimenetek a vállaltok számára alapvetően megfelelnek, a képzéssel elégedettek. Számos szakmai és humán kompetencia iránti igény is erős, ezek képzési szerkezetbe történő integrálása a közeljövő kihívásai közé tartozik. Emellett a valós piaci igények folyamatos kihívást jelentenek a Kar számára a képzési szolgáltatásaink fejlesztésére.
\end{abstract}

Abstract: In this study, we have investigated the relationship between the training portfolio of University of Szeged Faculty of Engineering and the corporate expectations, the requested competencies from graduates. The investigation was based on primary data surveys (questionnaires and interviews).

The results have shown that the professional output (the skilled students) from the Faculty is basically adequate for the companies and the firms are satisfied with the training.

There is a strong demand for a number of professional and human competencies from the companies and integrating these into the training structure is one of the challenges in the near future. In addition, the real market demands from the labour market are a constant challenge for the Faculty to develop or training services.

Kulcsszavak: kompetencia, tudásigény, felmérés, felsőoktatás, EFOP

Keywords: competency, knowledge needs, survey, higher education, EFOP

\section{Bevezetés és célkitüzés}

A kutatás célja a hallgatói tudás és kompetenciaszintek és a munkaadói igények közötti kapcsolat és elvárás feltérképezése. Ehhez a központi Képzési és Kimeneti Követelménytrendszert $(\mathrm{KKK})$, valamint a munkaadók elvárásait igyekeztünk felmérni. (18/2016. (VIII. 5.) EMMI rendelet)

Első lépésként az egyes szakokkal kapcsolatos KKK-ban kiadott szakszintü leírásokat és követelményeket rendszereztük.

A KKK-ból kigyüjtött kulcsszavak alapján kérdőívet készítettünk amit a leendő munkaadókkal töltettünk ki.

Feltételeztük, hogy a válaszadó jobban eligazodik ha konkrétabb egyértelmübb kulcsszavas technikával kérdezzük le, mintha a KKK anyagát szó szerint alkalmaznánk.

A kérdőíves felmérést mélyinterjúkkal egészítettük ki.

A kutatás célja: Meghatározni azokat a releváns munkadói kompetenciákat (szakmai, humán, stb.) melyek a legmeghatározóbbak a munkarőfelvétel, illetve karriertervezés területén; ezen belül azonosítani azokat, amelyek a Kar képzéseitől függnek és amelyeket fejleszthetjük.

A Karon oktatott szakirányokra általánosan jellemző követelmények között értelmezés szintjén sok az átfedés. Az alapvetően vizsgált négy kompetenciacsoport jellemzői a következők voltak: 
- A hallgató tudása

- A hallgató képességei

- A hallgató attitüdje, hozzáállása

- A hallgató autonómiája és felelőssége

\section{Anyag és módszer}

\subsection{Desk research adatelemzés}

Első lépésként a szakokra és a szakirányokra vonatkozó KKK-k rendszerezett áttekintését végeztük el. A kívánatos kompetenciákat a KKK a következő négy csoportba osztja.

- A hallgató tudása: értelemszerủen az oktatással összefüggő szakma tudásmennyiség.

- A hallgató képességei: A megszerzett tudás alkalmazásának mikéntje, hogyan tudja az ismereteket alkalmazni.

- A hallgató attitüdje, hozzáállása: Ezek humán kompetenciák, melyek közvetlenül nem szerepelnek a képzési tartalmak között, de a képzés folyamán indirekt módon történik rá utalás. (Karriertervezés, Kommunikáció)

- A hallgató autonómiája és felelőssége: Szintén humán kompetenciák, de egyes tantárgyakban részbeni oktatások megoldott. (Menedzsment ismeretek, Vállalkozásszervezés, Vállalatirányítás stb.)

\subsection{Első lekérdezés és mélyinterjú elkészítése}

Online kérdőívet készítettünk a Google kérdőívszerkesztő programjával, amit a partnerek e-mail listájára küldtünk ki. A visszaküldési arány nagyon alacsony volt, ezért többszöri ismétléssel is fel kellett hívtuk a partnerek figyelmét a kérdőívre.

A KKK-ból kulcsszavakat válogattunk ki, majd ezek lettek a kérdőív kérdéseinek alapjai. Alkalmaztuk mind a Likert skálás (osztályozza 1-5-ig az megjelölt kompetenciákat), mind a sorba rendezős (ordinális) technikákat.

A beérkezett kérdőívekkel párhuzamosan több mélyinterjút is készítettünk egyes cégek vezetőivel. Az interjúhoz a kérdőívben szereplő kulcsszavakat használtuk, de összességében szabad asszociációval részletesebb információkat sikerült kinyerni a kutatás számára.

\subsection{A második lekérdezés elkészítés}

Az első lekérdezés és a mélyinterjúk eredményeinek elemzése során egy szükített, jobban fókuszált második lekérdezéssel elemeztük a legfontosabbnak tartott kompetenciákat, melyek az első kérdőív alapján fontosnak mutatkozott a munkaadók részéről.

A kérdőívek adatait Microsoft Excel táblázatkezelő segítségével elemeztük, ezeket az eredményeket a mélyinterjúkból származó adatokkal információkkal helyesbítettük, illetve kiegészítettük. 


\section{Eredmények}

\subsection{A kérdőívek elemzése}

Az első kérdőívet összesen 23 cég küldte vissza, 14 felsővezető és 9 középvezető. A visszaküldő cégek telephelye a dél-alföldi régióra koncentrálódott, így Szeged, Röszke és Szentes adta a cégek többségét. Cégforma tekintetében a Kft. volt a meghatározó, de néhány nagyobb cég is kitöltötte a kérdőívet.

A lekérdezett cégek összesen 5700 föt foglalkoztatnak, 10 cégnek nincs exportja, a többi 13 cég változó exportárbevétellel rendelkezik (20-80\%). Összesen 2, teljesen külföldi tulajdonú cég volt a mintában, a többi hazai cég mely közül csak 1 cégben volt $15 \%$-os külföldi tulajdonrész.

Tevékenységi körök szerint, a cégek változó tevékenységeket végeztek. Megtalálható volt ipari, élelmiszeripari, elektronikai, háztartásvegyipari, mezőgazdasági alapanyag termelés is a mintában.

A Karunkkal való kapcsolat tekintetében a cégek főleg a duális képzéssel, illetve már korábban végzett hallgatókkal kapcsolódnak.

A Mérnök Karral való megelégedettséget is megkérdeztük; eszerint a cégek alapvetően elégedettek a képzés színvonalával (lásd: 1. ábra). Ezt kiegészítendő, megkérdeztük a cégek véleményét, hogy milyen elméleti-gyakorlati arányt tartanának kívánatosnak a képzés során. A válaszadók többsége az 1/3-1/3-1/3 arányt tartana jónak az elmélet, gyakorlati és a vállalati gyakorlat tekintetében.

\section{1. ábra: A képzési színvonal megítélése}

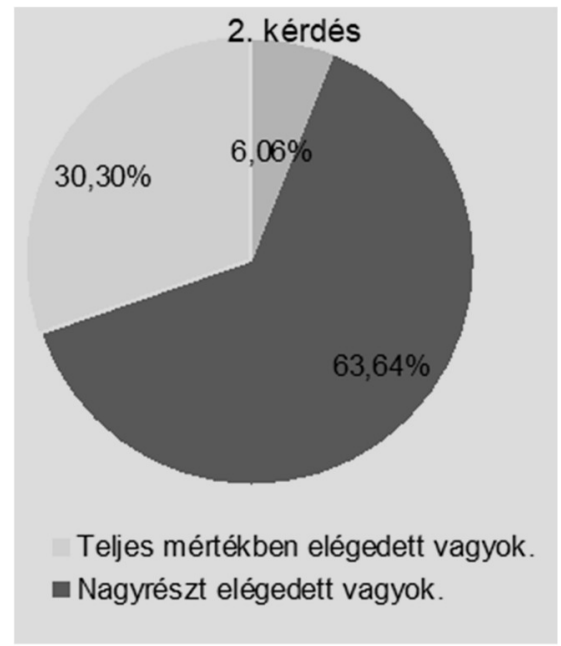

Forrás: A szerzők saját szerkesztése.

\subsection{A legfontosabb fejlesztendő területek}

Megkérdeztük milyen területen gondolkodik a vállalkozás fejlesztésben, elörelépésben.

A három legfontosabb terület súlyozott sorrendje a müszaki innováció, a marketing és a minőségmenedzsment. Ez egybevág a Kar képzési portfóliójával is. 
Ehhez a képzéshez leginkább a BSc végzettségủeket igénylik a cége; a szakmérnöki, illetve az MSc végzettség egyaránt fontos számukra, de a BSc vezeti a listát.

A cégek ismereteket és tudást, nem elsösorban az alaptudományok területén, hanem az alkalmazott tudományterületeken várnak. Ez abból fakad, hogy a vizsgálat a termelö-szolgáltató szférát érinti, ahol az alaptudományok önállóan nem hasznosíthatók, de a ráépülő alkalmazott és a gyakorlatban hasznosítható tudományok ismerete annál inkább elvárás.

\subsection{Kulcskompetenciák}

A kulcskompetenciák területén érdekes módon inkább a „soft” kompetenciák a fontosak (felelősségvállalás, megbízhatóság, motiválhatóság). A technikai, szakmai képességek is természetesen elvárás, de ez - mint a későbbi válaszokból kiderül - a szakmai készségek helyben fejleszthetőek (pl. céges képzésekkel). (Lásd: 1. táblázat, 2. táblázat)

\section{1. táblázat: A fontosabb kulcskompetenciák}

\begin{tabular}{|c|c|c|c|c|c|c|}
\hline Kulcskompetenciák & 5 & 4 & 3 & 2 & & $\begin{array}{l}\text { Ǒsszes } \\
\text { pontszám } \\
\text { (Nagyobb } \\
\text { érték } \\
\text { fontosabb) }\end{array}$ \\
\hline Csapatmunkára való képesség & 9 & 11 & 1 & 0 & 2 & 94 \\
\hline Felelôsségvállalás & 11 & 9 & 1 & 2 & 0 & 98 \\
\hline Vállalat iránt ielkötelezôdés & 3 & 13 & 3 & 2 & 2 & 82 \\
\hline |parági jártasság & 3 & 8 & 9 & 1 & 2 & 78 \\
\hline Eltöléltség/mot váció & 13 & 5 & 4 & 0 & 1 & 98 \\
\hline Döntéshozatali képesség & 4 & 11 & 4 & 4 & 0 & 84 \\
\hline Kommunikációs képesség & 4 & 11 & 6 & 0 & 2 & 84 \\
\hline Vezetési képesség & 1 & 11 & 5 & 4 & 2 & 74 \\
\hline Megbízhatóság & 15 & 4 & 2 & 0 & 2 & 99 \\
\hline Eredményorientáltság & 7 & 11 & 3 & 1 & 1 & 91 \\
\hline Szervezési képességek & 3 & 8 & 6 & 1 & 5 & 72 \\
\hline Technikai képességek & 3 & 7 & 9 & 2 & 2 & 76 \\
\hline
\end{tabular}

Forrás: A szerzők saját szerkesztése.

\section{2. táblázat: A fontosabb kulcskompetenciák}

\begin{tabular}{|l|r|r|l|r|}
\hline 3 legfontosabb kompetencia most & Gyakoriság (fö) & & 3 leg fontosabb kompetencia 2030-ban & Gyakoriság (fö) \\
\hline Szakmai tudás & 8 & & Kreat vitás & 7 \\
\hline Kreat vitás & 5 & & Szakmai tudás & 4 \\
\hline Megbízhatóság & 4 & Csapatmunka & 3 \\
\hline Csapatmunka & 4 & & Infokommunikációs eszközök ismerete & 3 \\
\hline Felelősségvállalás & 3 & & Felelösségvállalás & 2 \\
\hline Terhelhetőség & 2 & & Pontosság & 2 \\
\hline Problémamegoldó képesség & 2 & Rugalmasság & 2 \\
\hline Pontosság & 2 & Szaktudás & 2 \\
\hline Önállóság & 2 & Alapos elmélet itudás & 1 \\
\hline Mot váció & 2 & Alkalmazkodóképesség & 1 \\
\hline Lojalitás & 2 & Bérek & 1 \\
\hline Hozzáállás & 2 & Csapatmunkára való képesség & 1 \\
\hline Vezetői képesség & 1 & Csapatszellem & 1 \\
\hline
\end{tabular}

Forrás: A szerzők saját szerkesztése. 


\section{Fontosabb egyéb kompetenciatípusok említésének gyakorisága és értékelése}

\subsection{Humán kompetenciák}

Kiugróan magas a kooperáló csapattag mint elvárás a humán kompetenciák között. Természetesen ez a tulajdonság szorosan kapcsolódik olyan említett pozitív tulajdonságokhoz, mint a

1. kommunikációs képesség,

2. vitakészség,

3. kreativitás stb.

Ugyanitt a terhelhető és a megbízható, mint alaptulajdonság szintén a soft tulajdonságok közé tartozik.

\subsection{Szakmai kompetenciák}

A szakmai kompetenciák közül természetesen a szaktudás és annak felelös alkalmazása volt a szempont. Konkréten az alábbi kompetenciákat tartották fontosnak a cégek.

1. Legyen naprakész (szakmailag).

2. Ismerje az iparág helyzetét, folyamatait.

3. Folyamatos az önképzési igény.

4. Képes folyamatokat menedzselni.

Részletesebben a 2. ábra tartalmazza a szakmai kompetenciák fontossági sorrendjét az említett kérdésekre. Jól látszik, hogy igen jelentős eltérés van az említések számában.

\section{2. ábra: Szakmai kompetenciák fontossági sorrendben}

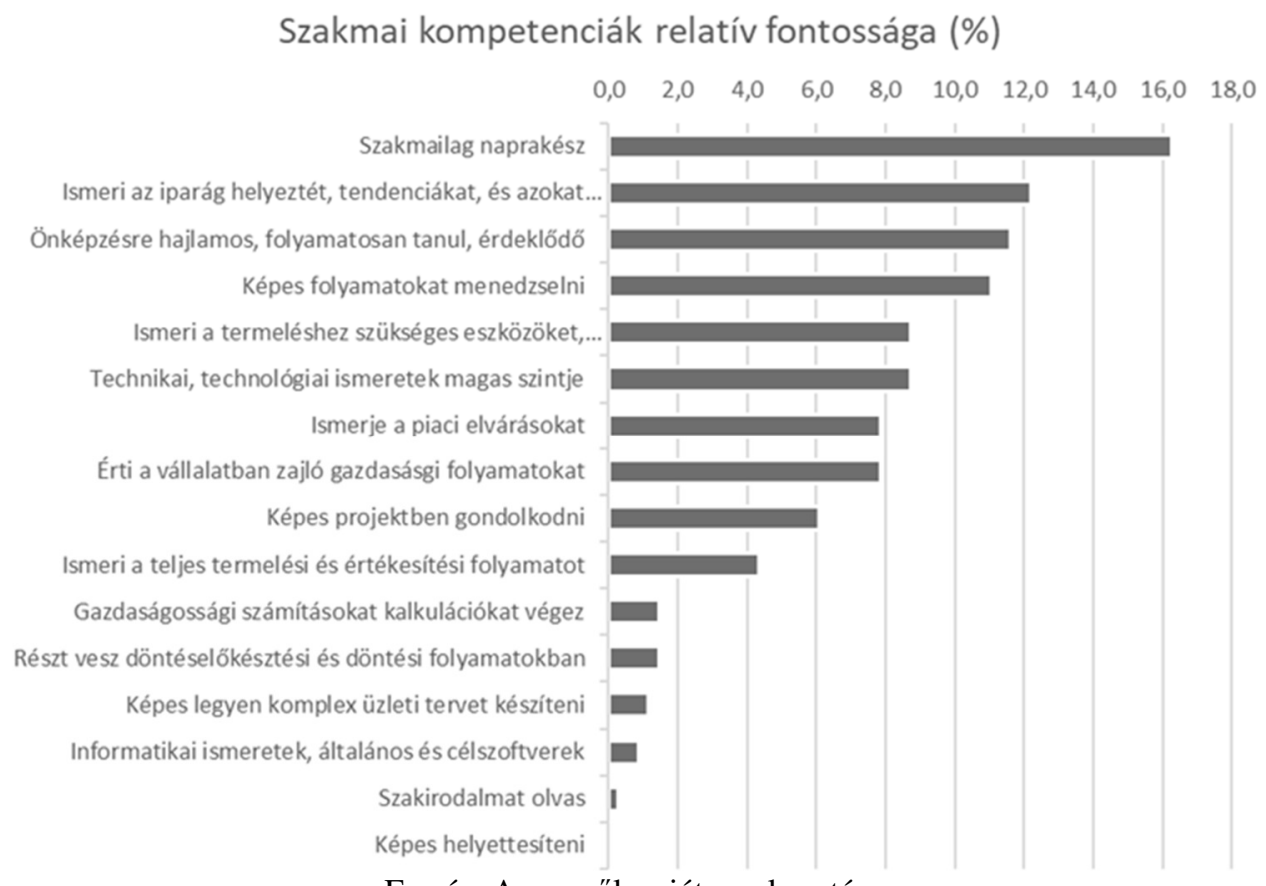

Forrás: A szerzők saját szerkesztése. 


\subsection{Kommunikációs kompetenciák}

A legfontosabb elvárások a kommunikáció területén:

1. Képes megoldásokat keresni.

2. Képes csapatban dolgozni.

3. Jól és hatékonyan kommunikál.

4. Szakmai kapcsolatokat ápol.

Ezeket a tulajdonságokat nehéz fejleszteni, hiszen az oktatásban a Karon a szakmai képzés dominál. Ennek ellenére számos tantárgyhoz az említett tulajdonságok kapcsolhatók (gazdasági tantárgyak, esettanulmányok, gyakorlati képzési helyek stb.)

\subsection{Vezetői kompetenciák}

Megvizsgáltuk a vezetőktől elvárható kompetenciákat is, hiszen hallgatóink jelentős része közép- vagy felsővezető lesz az adott munkahelyen.

A legfontosabb követelmény itt a felelősségvállalás, a motiváltság (elkötelezettség), és a döntésképesség.

Természetesen a többi tulajdonság jelentős része ezek függvénye. Érdekes módon, ha külön említjük meg a fogalmakat, az önkritika nem elvárás, illetve nem volt a legfontosabb 5 jellemzőben a szempontok között.

Megjegyzés: Ezek a kompetenciák oktatása, fejlesztése nem, vagy csak részben érintik a képzésünket; ezek a kompetenciák a személyiségfejlesztés, személyiség fejlődés során alakulnak ki, természetesen a környezeti hatások eredményeképp is.

\section{3. ábra: Vezetői kompetenciák}

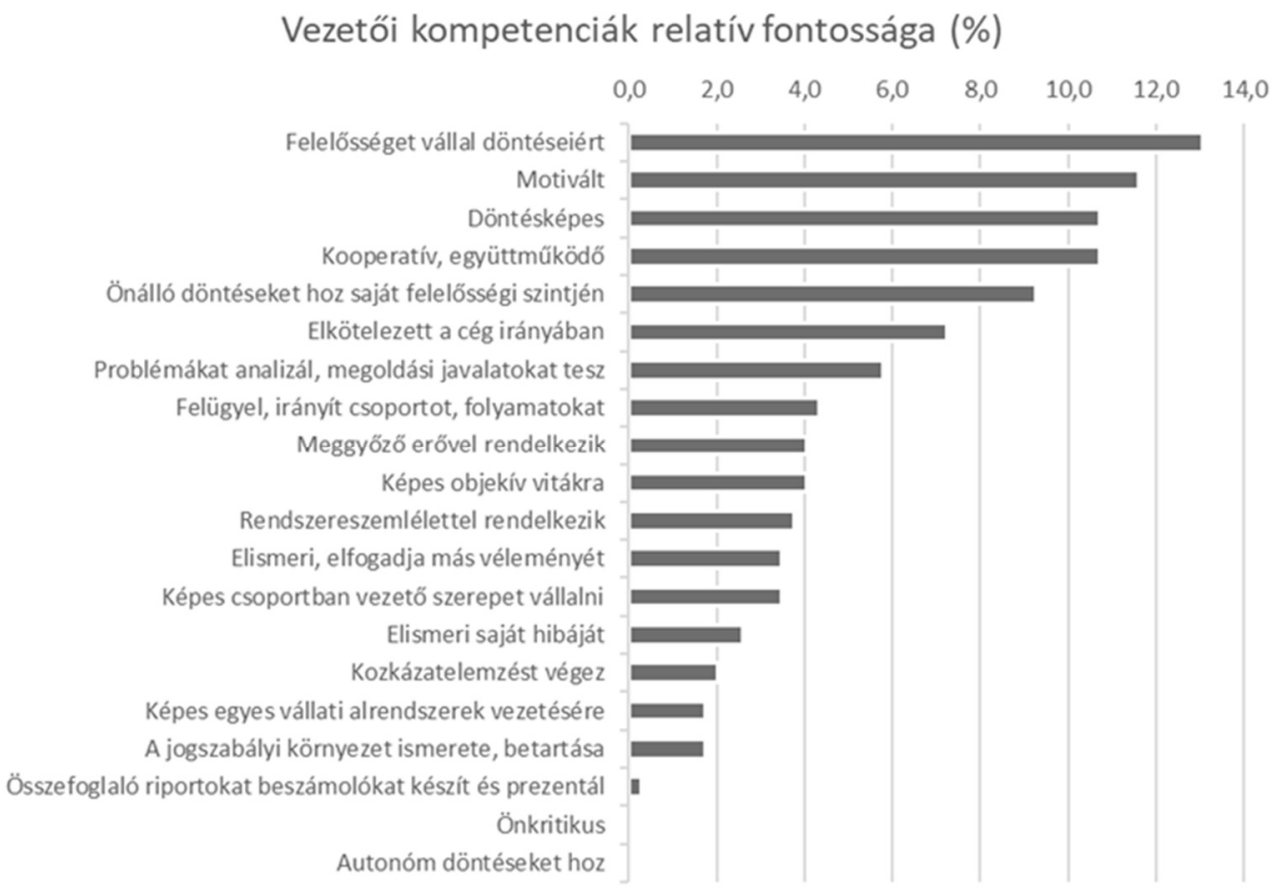

Forrás: A szerzők saját szerkesztése. 


\section{További elemzések}

Az eredménynek feldolgozásából (kérdőívek és a mélyinterjúk statisztikai elemzése) kapcsán arra a megállapításra jutottunk, hogy a munkaadóknál a szakmai (hard) és a soft kompetenciák egyaránt fontosak. A legfontosabb kérdések arra vonatkoztak, milyen fejlesztési javaslatokkal segítheti a piaci szereplő a Kar képzését, milyen ismeretanyagokat igényel a végzett hallgatóktól.

\subsection{Milyen új ismeretanyag beépítését javasolják a Kar BSc és MSc képzéseibe?}

Ez egy szabadon kitölthető mező volt a kérdőívben, az adott válaszok $\mathrm{ABC}$ sorrendben, de mindenféle súlyozás nélkül szerepelnek. Külön kiemelendő, hogy az ERP rendszerek képzése a vállalatirányítás tantárgy keretében két éve már bevezetésre és oktatásra került. A kiemelt sorokkal jelezzük, az oktatási portfólióban már meglévő tárgyakat, illetve tevékenységeket

Munkaadók által kívánatos képzések és tevékenységek (nem fontossági sorrend)

1. aerodinamika

2. automatizálási szakirányú képzések pl. pneumatika, hidraulika, PLC

3. csapatmunkát elősegítő képzések

4. csúcstechnikák, technológiák oktatása

5. digitalizáció és automatizálás,

6. digitalizáció, digitális gyárak; hidraulika/arányos hidraulika

7. doktori képzés

8. energetika; gyártó rendszerek optimalizálása; értékesítés

9. energetika; müszerek; logisztika (gyártórendszer logisztika!)

10. ERP rendszerek oktatása (SAP, Dynamics NAV stb.)

11. ERP rendszereken belül különösen a gyártás modul oktatása

12. felkészítés a munkákkal kapcsolatos kihívások kezelésére az életben

13. géptan; gépek üzemtana

14. gyakorlati géptervezési ismeretek

15. gyakorlati képzések erősítését javaslom

16. gyakorlati látogatások növelése

17. gyártótechnológiai vonalak tervezése, azok összehasonlítása,

18. idegen (angol, német, kínai, spanyol) szaknyelv oktatás;

19. informatika, idegen nyelv, együttmüködést-kommunikációt segítő képzések

20. innováció és környezetvédelem

21. jó és rossz megoldások a mérnöki gyakorlatban

22. készülék, szerszám tervezés

23. kockázatértékelés; önértékelés

24. kvalitatív statisztika

25. LEAN ismeretek

26. LEAN menedzsment

27. logisztika, gazdasági ismeretek mérnököknek

28. logisztikai képzés

29. minél több laboratóriumi, teszt feladatok; gyakorlati problémák konkrét megoldása; 
30. programozási gyakorlatok, konkrét feladatok;

31. PLC programozási gyakorlatok

32. precíziós technológia, mg-i digitalizáció

33. problémamegoldó készségek fejlesztése,

34. project management

35. projekt-határidőmenedzsment;

36. rendszerépítés; kommunikáció;

37. robotika és digitális technológiák

38. SAP, vállalatirányítás

39. szakismeretek folyamos frissítése

40. szakmai napok,

41. szervezés és vezetés;

42. szimulációs programok,

43. vállalatok, vállalkozások fejlődési lehetőségei a globalizálódó gazdasági környezetben

A válaszokban az ismétléseket kiszürtük.

\section{Következtetések}

A felmérés befejező szakaszában a beérkező adatok alapján a következő fontosabb megállapítások tehetők.

- A Kar és a piaci szereplők kapcsolatrendszere folyamatosan nő, de a tartalmi kérdésekben a konkrétabb $\mathrm{K}+\mathrm{F}$ és közös projektek irányában kell elmozdulni.

- A partnerek a Kar képzésével alapvetően elégedettek (szakmai képzés), ugyanakkor olyan kompetenciákat is elvárnak el a végzett hallgatóktól, amelyek inkább a humán kompetenciák közé tartoznak (nincs tantárgyasítva).

- A kifejtős kérdésekben alkalmazott kulcsszavas (szófelhő alapú) elemzések vizuálisan jól mutatják az egyes tulajdonságok, kompetenciák fontosságát mind a munkaerő mind a piaci folyamatok jelenbeli és jövőbeni elvárásainak függvényében.

- A piaci szereplők tudatában vannak a közeljövőben várható paradigmaváltásnak, amit a fokozódó automatizáció és robotizáció okoz a piacon. A változások pontos hatásmechanizmusa teljeskörüen nem ismert, de a tendenciák már érezhetőek, ez okkal stresszeli a piaci szereplőket, de jelentős kihívások elé állítja az oktatást is.

- A munkaerőtől elvárások tekintetében a felsorolt kompetenciákból a legfontosabbaknak az egyéni kompetenciákat tartják (megbízhatóság, kreativitás, önállóság, felelösség stb.), de a csoportban való munkát (csapatmunka, kommunikáció) is megemlítik.

- A vállalatok legfontosabb kihívása a müszaki innovációval kapcsolatos lépéstartás, valamit a minőségmenedzsment. Hasonlóan fontos a $\mathrm{K}+\mathrm{F}$, és a vállalati tervezés fejlesztése, amire más kérdésekből adódó válaszok is utalnak. 
- A folyamatos képzéseket minden tekintetben fontosnak tartják a vállalatok leghatékonyabbnak a szaklapokat, és a rövid képzéseket tartják (céges, illetve egyetemi). Ugyanakkor a gyakorlatiasabb kézzelfoghatóbb képzésekre való igény is megjelenik a javasolt képzésfejlesztési listában (több gyakorlat, céglátogatás,

- Alapvető elvárás a BSc, és az MSc képzési kimenet, a piacon a $\mathrm{PhD}$, illetve a magas tudományos végzettség általában nem elvárás (a vizsgált célcsoport mintáján).

- A legfontosabb elvárt tulajdonságok munkaadó szemmel, a megbízhatóság, eltökéltség, motiválhatóság és a pontosság. Ezek - véleményünk szerint általános elvárások a munkaerőpiacon, nem korlátozódik a müszaki végzettségü hallgatókra.

- A vállalatok tudatában vannak a közeljövőben bekövetkező változásoknak (robotizáció, technológia stb.), ugyanakkor nincs (és nem is lehet) pontos recept a változások menedzselésére (egyszerre nagyon sok tényező változik).

\section{8. Összefoglalás}

Az eredménynek feldolgozásából (kérdőívek és a mélyinterjúk statisztikai elemzése) kapcsán arra a megállapításra jutottunk, hogy a munkaadóknál a szakmai (hard) és a soft kompetenciák egyaránt fontosak.

A legelső és legfontosabb szempont a mai munkaerőpiaci helyzetben, hogy legyen szakmailag megfelelő munkaerő, amennyiben azzal rendelkeznek, akkor kerülnek előtérbe a soft kompetenciák,

Az adatokból is látható, hogy a munkaadók számára az egyik legfontosabb kompetencia a megbízhatóság, csapatban való gondolkodás, terhelhetőség.

Ezt kiegészítendő, megkérdeztük a cégek véleményét, milyen elméletigyakorlati arányt tartanának kívánatosnak a képzés során. A válaszadók többsége az 1/3-1/3-1/3 arányt tartana jónak az elmélet, gyakorlati és a vállalati gyakorlat tekintetében.

Itt jegyezzük meg, hogy kaptunk néhány visszajelzést arra vonatkozóan, hogy a felmérésnek olyan hozadéka is van, hogy ráirányította a figyelmet a kompetenciák szerepére, a kompetenciákban való gondolkodás fontosságára, ami nagy jelentőséggel bírhat a jövőben a kompetenciaalapú munkaerő kiválasztás és fejlesztésre áttérők körében a hatékonyabb humánerőforrás gazdálkodás, ezzel együtt a hatékonyabb, eredményesebb és fenntarthatóbb vállalati müködés előmozdításában.

\section{Köszönetnyilvánítás}

Jelen tanulmány a Szegedi Tudományegyetemen készült az Európai Unió támogatásával. Projekt azonosító: EFOP-3.4.3-16-2016-00014. 


\section{Irodalomjegyzék}

18/2016. (VIII. 5.) EMMI rendelet a felsőoktatási szakképzések, az alap- és mesterképzések képzési és kimeneti követelményeiről, valamint a tanári felkészítés közös követelményeiről és az egyes tanárszakok képzési és kimeneti követelményeiről szóló 8/2013. (I. 30.) EMMI rendelet módosításáról. <https://net.jogtar.hu/jogszabaly?docid=A1600018.EMM\&timeshift=fffffff4\& txtreferer $=00000001 . \mathrm{TXT}>(2018.03 .12$.) 